\title{
BRITAIN'S FIRST COMMUNITY ORTHODONTIC SCHEME: FOR THE CHILDREN OF HESTON AND ISLEWORTH
}

\author{
by
}

\author{
STANLEY GELBIER*
}

\section{THE NEED FOR ORTHODONTICS}

Orthodontics is the correction of irregularities of the teeth and jaws. Although frequently thought to be a modern concept, orthodontics was being taught in the United Kingdom by at least $1880 .^{1}$ At that time, Oakley Coles was lecturing on congenital deformities to students at London's National Dental Hospital (later to become the dental department of University College Hospital) and its associated dental school, the Metropolitan School of Dental Science. His book on deformities of the mouth, ${ }^{2}$ which included accounts of the orthodontic treatment of cleft palate cases, was published in 1870; but Joseph Fox's classical treatise, The natural history of the human teeth published in 1803, was the first book in England to include explicit directions for correcting dental irregularities. However, Pierre Fauchard had described and illustrated various appliances for the treatment of irregularities of the teeth in 1728, in his book Chirurgien dentiste. The theme of aetiology and treatment of irregular teeth was taken up by a number of mid-nineteenth-century dentists. So keen was interest in the subject that in 1907 eleven enthusiasts founded the British Society for the Study of Orthodontia (BSSO). ${ }^{3}$ However, one of their members pointed out the anomaly of mixing Greek words with a Latin ending, so orthodontia was replaced by orthodontics.

It was in the same year that the forerunner of the UK school dental service came into existence, George Cunningham's famous Cambridge Dental Institute for children, opening in Cambridge as a result of a private benefaction. ${ }^{4}$ The development of such clinics is not surprising: gross oral pain and sepsis was found in the nation's children; and many potential recruits to the forces were rejected because

*S. Gelbier, PhD, LDSRCS, DDPH, DHMSA, Department of Community Dental Health, King's College School of Medicine and Dentistry, c/o St Giles Hospital, St Giles Road, London, SE5 7RN

${ }^{1}$ B.C. Leighton and R.D. Howard, 'Orthodontics - the last hundred years', Br. dent. J., 1981, 151: 14; also 'Dental student supplement', Br. J. Dent. Sc., 1880, 23: 873-897.

2 J.O. Coles, Deformities of the mouth: their mechanical treatment, 2nd ed., London, Churchill, 1870.

${ }^{3}$ Present at the first meeting on 21 October 1907 were J.H. Badcock, H. Chapman, M. Hopson, A.C. Lockett, W.F. Mellersh, G. Northcroft, M. Philpotts, J. Sim Wallace, J.E. Spiller, E.R. Tebbitt, and H.C. Visick. See B.C. Leighton, 'The British Society for the Study of Orthodontics', Br.dent.J., 1968, $124: 425$.

‘H.C. Davis, 'George Cunningham: the man and his message', ibid., 1969, 127: 531. 


\section{Britain's first community orthodontic scheme}

of bad teeth. ${ }^{5}$ The main priority was thus tooth extraction. Only later did the emphasis shift from extractions to reparative fillings, so there could be no question of including orthodontic care in the earliest dental health schemes.

When discussing the need for orthodontic care, a 1922 report from the BSSO's education committee chaired by J.H. Badcock reminded the Society's members that: "So far as a large section of the population is concerned, it is not met at all". Badcock's committee stated that it was especially true for most poor children, but the situation in private practice was hardly any better: "even when the parents are willing to have it done". Few children of any kind received such care in dental hospitals; and orthodontic treatment was rarely undertaken in school clinics: "except insofar as extraction of the teeth, unaccompanied by any supplemental regulation, suffices". "

Nevertheless, by the late 1920 s, thought was being given to the problem by a few local authorities, for example, Croydon, Ealing, Heston and Isleworth, and the London County Council. ${ }^{8}$ The present paper examines the development of the Heston and Isleworth scheme, the first comprehensive community orthodontic programme in the United Kingdom. The initial phase of this scheme was in operation by 1929, and it was extended substantially in 1931, 1932, and 1933.

\section{HESTON AND ISLEWORTH}

In 1911 Heston and Isleworth were two parishes which together formed a single urban district in the county of Middlesex, occupying eleven square miles to the north-west of London. Table 1 demonstrates the growth in population during the period under discussion, as well as the fall in the infant mortality rate.

TABLE 1: HESTON AND ISLEWORTH,

$\begin{array}{cccr}\text { Year } & \text { Population } & \begin{array}{c}\text { Infant Mortality } \\ \text { Rate (per 1,000) }\end{array} & \begin{array}{r}\text { IMR } \\ \text { (England) }\end{array} \\ 1911 & & & \text { N.A. } \\ 1921 & 43,316 & 162 & 80^{*} \\ 1931 & 46,664 & 57^{*} & 66 \\ & 76,254 & 49.14 & \\ & & \left(^{*}=1920\right) & \end{array}$

The Urban District Council had a maternity and child welfare committee responsible for the health and welfare of mothers and young children; an education committee, responsible not only for the education of children attending elementary schools, but also for their health and welfare (the responsibility for secondary schoolchildren lay with the county council); and a health committee for its public

\footnotetext{
s See S. Gelbier and S. Randall, 'Charles Edward Wallis and the rise of London's school dental service', Med. Hist., 1982, 26: 397.

B J.H. Badcock, 'Report of the Education Committee to the British Society for the Study of Örthodontics', Trans. B.S.S.O., 1922, p. 57.

7 Ibid.

${ }^{8}$ See London County Council (LCC), Annual report for 1915 to 1919, vol. 3, Public Health, 1919, p. 68, and LCC, Annual Report for 1928, p. 109.
} 


\section{S. Gelbier}

health functions. Care for all groups was provided through a joint Public Health Department. At its head, was a medical officer of health $(\mathrm{MOH})$, who also acted as the school medical officer (SMO). Table 2 lists the MOHs for the period under consideration.

TABLE 2: MEDICAL OFFICERS OF HEALTH FOR HESTON AND ISLEWORTH, 1909-1938

$\begin{array}{ll}\text { Year } & \text { MOH } \\ 1909 & \text { George Frederick Buchan, MD, DPH } \\ 1912 & \text { Thomas Strain, MD, DPH } \\ 1916 & \text { William Bramwell Reid, MB, DPH } \\ 1919 & \text { William Arthur Berry, MD, DPH } \\ 1924 & \text { Elwin Harral Thomas Nash, MRCS, LRCP, DPH }\end{array}$

At that time, the district had many worse problems than teeth to worry about. The death rate was 13.58 , with an infant mortality rate of 162 per thousand births; ${ }^{9}$ and there were seventeen deaths from measles, whooping-cough, scarlet fever, diphtheria, and enteric fever. Indeed, it had one of the highest mortality rates in Middlesex. Nevertheless, the MOH and SMO, George Buchan, and his colleagues reported comprehensively on the state of schoolchildren's dental health. Although 64.4 per cent of children presented with decayed teeth, few had received dental treatment: only twenty children out of 973 examined had any teeth extracted or filled. This state of affairs led Buchan to tell the education committee: "Dental treatment is certainly required in a large number of these cases, but looking to the future, the important point ... is Prevention."10

In spite of Buchan's dental observations, it was not until 3 October 1918 that George Edward Fritche, LDSRCS Eng, became Heston and Isleworth's first school dentist, working at the Alexandra School Clinic. ${ }^{11}$ By then, Bramwell Reid was the $\mathrm{MOH}$ and SMO. Fritche was replaced as part-time dentist in the following April by Isaac Cohen, a name associated with Heston until 1941. He had gained his Licence in Dental Surgery from the Royal College of Surgeons of England in 1898. It was also in 1919 that general anaesthetics were first used in the dental clinic.

ELWIN H. T. NASH

In 1924, Elwin Harral Thomas Nash, MRCS, LRCP, DPH, was appointed as $\mathrm{MOH}$ and SMO of Heston and Isleworth. Born in 1872 in Guernsey, he was educated at St Paul's School and St Thomas's Hospital. Nash gained his conjoint diploma in 1896. After filling house posts in several departments at St Thomas's, he became a general practitioner in Accrington. However, Nash's interests turned to public health. He gained his Diploma in Public Health from the Victoria University, Manchester; held a public health research scholarship; went to Derby to take charge

- 1911 annual report of the medical officer of health for the year ending 31st December 1911, Health Committee of the Urban District of Heston and Isleworth, 1912, p. 54.

${ }^{10}$ Fourth annual report of the school medical officer for the year ending 31 st December 1911, Education Committee of the Urban District of Heston and Isleworth, 1912, p. 13.

${ }^{11}$ Eleventh annual report of the SMO, Urban District of Heston and Isleworth, 1919, p. 6. 
of the isolation hospital; became assistant $\mathrm{MOH}$ at Derby; and then $\mathrm{MOH}$ of Wimbledon.

According to his obituary, Nash was no ordinary official: "The fire of the enthusiast burned bright in his eye as each year added to his age". ${ }^{12}$ Years earlier, he had concluded that many of the nutritional problems of the nation could be solved if it were taught to buy better and to cook more skilfully. He thus wrote a sixpenny, 183-page Dr Nash's cookery book, published in 1937 by Simpkin Marshall-but only after he learned to be a first-class cook. Nash was one of the first officials to commence immunization against diphtheria on a large municipal scale. Orthodontics was a further interest.

It is Nash's name rather than Cohen's which appears frequently in the records as pleading with the education committee for the development of orthodontic care. Perhaps this pattern simply followed the pre-1974 model, when the dentist was not a chief officer to his health or education authority. He almost invariably had to work and report to the local authority council committees through the MOH/SMO. Nevertheless, it is clear that Nash did take a close personal interest in the development of the community orthodontic care scheme at Heston and this was recognized by the dental profession. ${ }^{13}$ Indeed, by 1935 , he had been made an Honorary Fellow of the American Stomatological Association. ${ }^{14}$

\section{THE NEED FOR A LOCAL SCHEME}

It may be coincidence that the orthodontic scheme was first mooted in $1924 .^{15}$ Many children required more treatment than that usually given and sanctioned at school dental clinics (see Table 3). Cases were normally treated solely by the extraction of first permanent molars, the ultimate results being left to nature. Parents usually were unwilling to have teeth nearer to the front extracted, even when orthodontically necessary, in case any gaps remained visible.

TABLE 3: TYPES OF ORTHODONTIC PROBLEMS FOUND AT THE HESTON AND ISLEWORTH DENTAL CLINIC IN THE EARLY DAYS

(Modified after Nash, 1930)

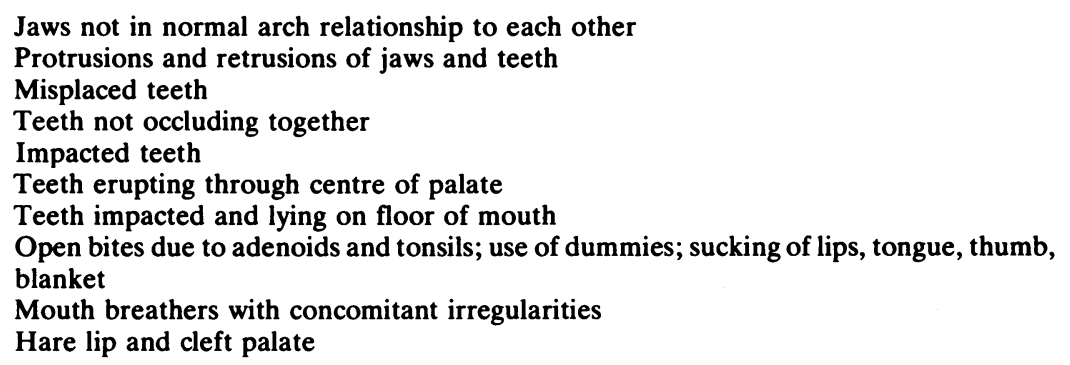

12 Obituary. 'E.H. Nash', Lancet, 1941, ii: 779.

13 See his lecture on 'Orthodontic schemes' delivered to the Home Counties Branch of the Society of Medical Officers of Health, reproduced in Public Health, 1936, 44: 384-391. Also, Nash's paper 'The work of the first orthodontic clinic in this country, at Heston and Isleworth', J. Royal Sanitary Institute, 1933, 56: 171-182, which outlines how he was appalled by the mouths of Council employees whom he had examined for a pension scheme.

${ }^{14}$ E.H.T. Nash, letter on 'Dental deformities' to editor of $\mathrm{Br}$. med. J., 1935, ii: 875.

is Seventeenth annual report of the SMO, Heston and Isleworth, 1925, p. 15. 


\section{S. Gelbier}

Sir George Newman, chief medical officer of the Board of Education, maintained that most orthodontic treatment should be carried out at a dental hospital. ${ }^{16}$ Initially, Nash obtained consent from the education committee to purchase a limited number of Royal Dental Hospital (RDH) subscription treatment tickets, which were given to selected and suitable children. The cost to the district was one guinea for four letters. ${ }^{17}$ However, Nash and Cohen found that few orthodontic cases were actually treated because of ignorance and expense. Nash told the committee that it was difficult to make many dentally ignorant parents understand the need for treatment. Even a "gravely disfiguring deformity" was often ignored if parents suffered from a similar condition. What was good enough for them was good enough for the child. A further problem was that the tickets gave entitlement only to ordinary dental treatment: for appliance therapy a further dental hospital fee had to be paid in advance. To this cost had to be added travel and other expenses, a major factor, as orthodontic treatment required many visits for supervision and adjustments of appliances. As Nash said in a 1936 lecture to the Home Counties Branch of the Society of Medical Officers of Health: "Even now there is insufficient appreciation of what it means to a parent to come up to a London hospital from a district in the periphery." ${ }^{18}$ A journey from Heston to the Royal Dental Hospital in Leicester Square, a distance of twelve miles, meant rail fares for mother and child which varied from $2 s .3 d$. to $3 s . ;^{19}$ often the expense of some food; maybe carrying a toddler or baby who could not be left at home; the loss of up to a day's work if the mother was employed; and finally "a thoroughly exhausting day". ${ }^{20}$ The necessary multiple journeys were usually out of the question, except for the children of railwaymen, who got special passes. Some families of restricted means travelled by a workmen's train in order to save some of the cost and "loafed about London until noon when they were to be seen". ${ }^{21}$ As few families could stand the financial burden, treatment was frequently discontinued; and the value of any work done, including the cost of the hospital ticket, was lost.

Nash had a further worry. Those patients who went to the RDH were used for demonstration purposes: "And entirely misconceived opinions were reported to us as the result of these demonstrations to students in front of the parents." ${ }^{22}$ It quickly became apparent to Nash that if orthodontic care was to be effective, it would have to be carried out by the local school dentist acting on the advice of a dental hospital orthodontist, who could prescribe any necessary extractions and/or appliance therapy. And so, by 1924, the idea of a consulting orthodontist was conceived. Although it was a further five years before a true orthodontic scheme could commence, during 1924, ninety-eight cases were referred to hospital for orthodontic treatment. ${ }^{23}$

${ }^{16}$ Ibid.

${ }^{17}$ E.H.T. Nash, 'Orthodontic schemes', Public Health, 1936, 44: 387.

${ }^{18}$ Nash, op. cit., note 14 above, p. 387.

$195 \mathrm{p}=1$ shilling $(1 s)=$.12 pence $(12 d$.).

${ }^{20}$ Seventeenth report, op. cit., note. 15 above, p. 15.

${ }^{21}$ Nash, op. cit., note 14 above, p. 387.

22 Ibid.

${ }^{23}$ Seventeeth report, op. cit., note 15 above, p. 15. 


\section{Britain's first community orthodontic scheme}

THE RDH CONNEXION

In $1924, \mathrm{Nash}$ asked the $\mathrm{RDH}$ to consider a co-ordinated scheme whereby its staff would act as diagnostic and advisory consultants, with any subsequent treatment being carried out in Heston's own dental department. Norman G. Bennett (a member of the original BSSO committee) read out Nash's letter to the medical committee of the hospital. ${ }^{24}$ They agreed in principle to co-operate with Heston, but referred the matter to a special children's sub-committee consisting of A.T. Pitts, E.F. Ackery, Bennett, and W.H. Dolamore (the Dean of the school), with F.St.J. Steadman in the chair. ${ }^{25}$ This sub-committee, in writing to the Board of Education for advice,$^{26}$ acknowledged that orthodontics was not a regular part of school dental treatment but presumed that the omission was more due to lack of time than to any other cause: "Though probably the difficulties of diagnosis, treatment and manufacture of appliances have something to do with it."27 Although not proposing the general adoption of orthodontic treatment in schools, they reminded the Board that many forms of malocclusion and abnormal development of the jaws and dental arches were associated with defects of speech and mastication, and might be classed as serious physical disabilities which ought, if possible, to be remedied. They therefore asked if hospital staff should help out, as most school dentists were "insufficiently experienced to make reliable diagnoses", although "continuation of treatment should be well within their capabilities". The hospital thus felt that the best way forward would be for opinions to be given on referred cases very much in line with Nash's view.

Within a month, Newman replied that the Board agreed completely with the hospital's view, and would be prepared to welcome any proposals from local education authorities along the lines suggested. ${ }^{28}$ Although trying to be helpful, Newman was aware of the need for caution, because of the potential size of the problem. He wrote: “We could hardly initiate such proposals ourselves [but] I will communicate with my colleagues in order that they may raise the subject unofficially in the course of their inspections." Another letter to Newman indicated that the RDH was happy to act in a consultative capacity, but as it would be in addition to the ordinary work of the hospital, suggested a fee of half a guinea to include consultation, radiographs, and a written report. ${ }^{29}$ School dental officers would then be able to undertake cases with more confidence than their own personal experience might allow. Recognizing that dental officers had no facilities to manufacture even simple dental appliances, the RDH indicated its willingness to supply them. Continuation of treatment would then rest with the local dental officers. The RDH suggested that if its scheme was considered feasible by the Board of Education, a circular letter should be sent to education authorities within reasonable reach of the hospital telling them what was proposed.

24 RDH Medical Committee, Minutes, 3 April 1924.

25 Ibid., 22 May 1924.

${ }^{26}$ Ibid., 3 July 1924.

${ }^{27}$ Ibid., 3 July 1924, draft letter

28 G. Newman, letter to RDH, 5 August 1924

${ }^{29}$ RDH Children's Sub-committee, Minutes, 18 December 1924 


\section{S. Gelbier}

Correspondence between Heston, the RDH, and the Board continued for a long time. Nash felt that the hospital was not giving him sufficient help. In April 1927, a further letter to the medical committee again asked if arrangements could be commenced for orthodontic consultations. ${ }^{30}$ In June, the management committee agreed that the work be undertaken as a one-year experiment on the usual conditions for subscribers to the hospital. ${ }^{31}$ Consultations and negotiations continued between Cohen, Nash, and the RDH, but it was 1929 before permission was obtained from the Board of Education for Heston and the hospital to establish "a complete orthodontic scheme". ${ }^{32}$

Meanwhile, the Board had been seeking advice. Towards the end of 1929, A.T. Pitts, DSO, MRCS, LDS, dental surgeon to the Royal Dental Hospital and the Hospital for Sick Children at Great Ormond Street, was asked to make a detailed inspection of the arrangements made by a sample of local education authorities for dental inspections and treatment in their localities. Pitts found the question of orthodontic work in the school dental service "admittedly difficult" ${ }^{33} \mathrm{He}$ suggested that it would be unwise to divert a large proportion of the available funds required for routine dental treatment to "this particular sideline of the work". Nevertheless, he did recommend how urgent orthodontic care could be provided: "Special dental centres in large towns; district hospitals; laboratories at county headquarters; ... employment of a mechanic who could make regulation appliances."

In January 1930, the children's sub-committee, which included Herbert Reginald Evans, LDSRCS Eng, orthodontic demonstrator in the children's department, reconsidered Nash's scheme. ${ }^{34}$ They recommended acceptance of the general principle of the scheme for one year. However, they stipulated that when special work of the kind envisaged was undertaken for a public authority, part of the consultation fee of half a guinea should be allocated to a special fund: one shilling to the hospital, 9s. $6 d$. to the surgeons. The former should cover the extra cost to the hospital: clerical work in preparing a special register of cases; preparation and storage of models; sometimes radiographs; and preparation of typewritten reports.

In response to a request from Nash about making difficult appliances beyond the skill of Heston's mechanic, it was agreed that they should be constructed at the RDH, with the cost reimbursed by the district council. The recommendation of the children's sub-committee was approved in February 1930 by the hospital's committee of management. ${ }^{35}$ However, it was a further nine months before Nash was able to inform the RDH that the Board of Education had approved the scheme. ${ }^{36}$

Nash clearly was a good friend of dentistry, but it must not be thought that all was always in order between Nash and Cohen. Indeed, Nash had poor relations with

${ }^{30}$ E.H.T. Nash, letter to J.G. Turner, 7 April 1927

31 RDH Management Committee, Minutes, 2 June 1927

32 'Report of the school dental surgeon', in Twenty-second annual report of the SMO, Heston and Isleworth, 1930 p. 48.

${ }^{23}$ A.T. Pitts, 'Report on the school dental service', in Annual report of the chief medical officer of the Board of Education, 1929, p. 67.

24 RDH Children's Sub-Committee, Minutes, 31 January 1930.

${ }^{25}$ RDH Management Committee, Minutes, 7 February 1930.

${ }^{36}$ RDH Management Committee, Minutes, 4 November 1930. 
many people. On 23 November 1927, a visit was made to Heston and Isleworth by an inspector from the Board of Education. He was met by Councillor Heath (a member of the education committee), Mr Armstrong (director of education), Nash, Dr Roberts (assistant SMO), and Cohen. The inspector wrote: "Dr Nash is able and keen, but his manner is rather provocative to certain members of his authority on the one hand, and to his assistants on the other. The strained relations between him and the director, which are in most part due to the somewhat subversive methods of the latter, do not conduce to the smooth running of the service." ${ }^{37}$ The visitor went on: "Mr Cohen has not an engaging personality, but Dr Nash, by no means prejudiced in his favour, admits that he is an extremely rapid worker, dexterous operator and on the whole a sound dentist." So perhaps Nash had a grudging respect for Cohen.

\section{THE 1929 SERVICE FOR THE COMMUNITY}

By 1929, many children needed treatment for "disfiguring deformities" or to attain an "efficient masticating machine". The new scheme was designed to decrease dramatically the number of visits to the RDH. Following a meeeting with the RDH secretary, Cohen wrote to him that all future cases sent to the hospital should be seen for "consultative purposes" only; the orthodontic specialist was then to prescribe the correct treatment and explain why it was necessary. ${ }^{38}$ In December, Evans reported on his detailed discussions with Nash. ${ }^{39} \mathrm{He}$ confirmed that the scheme was urgent, with many children waiting for care. It was agreed that patients could bring with them to the hospital models of their mouths, so as to save time and curtail the number of visits.

Cohen intimated that his authority would pay ten shillings (10s.) for each ticket, in return for which it would require a full diagnosis and treatment plan, including any necessary pathological report and print of a radiograph. Eventually, a basic fee of $12 s$. was agreed. After consultation with mechanics and dental surgeons doing "this class of work", it was agreed that a further sum of $25 \mathrm{~s}$. would cover the cost of appliances, no matter how frequently the apparatus had to be adjusted or re-made. ${ }^{40}$ Thus, $37 s$. per case was to be charged irrespective of the amount of work involved.

Cohen was extremely grateful for all the help from the RDH. As he told the education committee: "I should like to place on record my thanks for the way in which the Secretary of the Royal Dental Hospital, and particularly Mr Evans the Surgeon to the Hospital in charge of this work, did everything they could to make the scheme workable."41 Although several schemes had been put forward, only the Heston and Isleworth scheme was considered by the RDH to be workable. ${ }^{42}$ In order

\footnotetext{
${ }^{37}$ See Report of visit by an unamed inspector from the Board of Education on 2 December 1927, in Public Records Office file PRO/ED 137/98.

'Report of the school dental surgeon', op. cit., note 32 above, p. 48.

39 RDH Management Committee, Minutes, 5 December 1929.

40 'Report of the school dental surgeon', op. cit., note 32 above, p. 50.

4 Ibid., p. 51.

42 For example, the LCC had considered a joint hospital/local authority scheme as early as 1919. See op. cit., note 8 above, p. 68. The LCC's 1934 Annual report, p. 83, indicated that until then no special arrangements had been made, although many children received treatment at the London dental hospitals. However, during the year three special orthodontic centres had been set up in the Deptford, Hammersmith and Prunella centres.
} 


\section{S. Gelbier}

to safeguard Heston's ratepayers, each case was inspected by a small sub-committee before being passed for treatment.

\section{A TRUE PUBLIC HEALTH SCHEME}

Negotiations with the RDH had been prolonged owing to the difficulty of agreeing a suitable scheme. Not only did Cohen want a workable scheme, but he sought to change the whole philosophy of teaching dental students, discouraging them from expensive care towards that more akin to the needs of poorer people: a true community programme. He wrote: "Hitherto dental students have been taught orthodontic treatment on lines which can only be applied to the well-to-do, and this to a considerable extent, one must say, on cosmetic grounds." 43 Cohen emphasized that the need to re-focus ideas about the practice of dentistry amongst people of limited means meant that teaching also had to change. In some ways, he was forecasting what the Nuffield Inquiry into Dental Education was to suggest some fifty years later, when it reported: "The usefulness of a profession depends on the extent to which it meets the needs of society for the services it provides, and social changes should therefore be mirrored in professional education." 44

Cohen continued to place great emphasis on the needs of the community as opposed to the more usual private practice, insisting on the need to bear in mind that cases must be seen "from the point of view of a Public Authority who cannot afford to treat in terms of Park Lane ... from the point of view of cost ... time and ... the difficulty in getting cases to attend." 45 In particular, he reminded the hospital that Heston's cases would be quite different from their more usual patients where "every person who comes is, so to speak, converted." It is difficult to know if he was correct in this assumption. Local authorities, he went on, unfortunately had to deal with a considerable number of "dental sinners": "Having got them to the penitential form we want the treatment carried out as simply and as rapidly as possibly."46

Cohen argued for a change in attitudes about teaching. In particular, he strongly disagreed with the view that "nothing but the best" must be taught to the dental student: another argument known well to today's public health or community dentists. Whilst admitting that all students should be taught the latest forms of treatment, no matter how expensive or prolonged, Cohen asked the RDH to face the fact that many new dentists might in future take up whole-time public dental appointments, or practise among people of "strictly limited means". If the latter were offered nothing but expensive and prolonged treatment, they would refuse it: there would then be no treatment at all except in the bigger towns with dental hospitals. So it was essential for students to know about methods of treatment that were economical, rapid, and obtained the best results possible. Cohen was thus suggesting that students should be taught two entirely different sets of treatment plans: for well-to-do patients under ideal conditions; and for others whose incomes were limited. He therefore arranged for the RDH to mark with asterisks all the cases referred from Heston so that they could be seen in the light of these circumstances.

48 'Report of the school dental surgeon', op. cit., note 32 above, p. 48.

" Dental education: report of a committee of inquiry, London, Nuffield Foundation, 1980, p. 25.

is 'Report of the school dental surgeon', op. cit., note 32 above, p. 49.

${ }^{46}$ Ibid. 
HOW THE SCHEME WORKED BETWEEN THE ROYAL DENTAL HOSPITAL AND THE CLINIC

\section{Payment for treatment}

Cohen spelt out the major advantage for the children of Heston and Isleworth. Instead of the previous multitudinous journeys to London, there would be only one, except in the rarest of instances. The remaining work would be carried out by the local school dentist and part-time mechanic.

At that time, even routine school dental treatment was not free, one shilling being charged for all treatment during the year, including administration of general anaesthetics, if necessary. In order to assess any parental contributions for orthodontic treatment, a special scale of fees was drawn up by the education committee (Table 4). To obtain the income per head, the total family income (less rent) was divided by the number of adults plus children. Parents who could not pay the whole sum were assessed by the chairman of the medical inspection sub-committee.

TABLE 4: SCALE OF CHARGES FOR ORTHODONTIC TREATMENT

$\begin{array}{ll}\begin{array}{l}\text { Income per head } \\ \text { (shillings) }\end{array} & \begin{array}{l}\text { To pay } \\ \text { (shillings) }\end{array} \\ \text { Less than } 8 \mathrm{~s} & 3 \\ \text { Between } 8 \text { and 10s } & 9 \\ \text { Between } 10 \text { and 12s } & 18 \\ \text { Above } 12 \mathrm{~s} & 37\end{array}$

It was agreed that an all-in fee of $37 \mathrm{~s}$. would both insure the education committee against financial loss and reduce the charge to the lowest amount possible. As experience was gained, this sum had conditions attached to it: (a) it could be paid in instalments: usually $2 s 6 d$., sometimes as low as $1 s$. per week; (b) no actual treatment beyond obtaining models of the case was allowed until $15 \mathrm{~s}$. had been paid; (c) if the consultant advised treatment by extraction only, the maximum charge would be $15 \mathrm{~s}$.; (d) in no case was the $15 \mathrm{~s}$. returnable, as it was needed to defray expenses. (e) Occasionally, the $37 \mathrm{~s}$. was reduced or cancelled. ${ }^{47}$ However, Cohen was careful to point out that free cases were treated in exactly the same way as those paying the $37 s$. ." "with the additional privilege that they had not to wait till the above $15 s$. was paid". When the fee of $37 \mathrm{~s}$. was paid in one sum, the committee gave automatic agreement to treatment; otherwise, the committee saw the child and interviewed the parents before giving a decision.

\section{The RDH contribution}

A report plus models of the teeth was sent to the hospital. After seeing the patient, the consultant sent a treatment plan to the clinic. If his assessment was that home co-operation would not be forthcoming, the prognosis was not good, or the potential results would not be of sufficient value to justify treatment, then he said so.

\footnotetext{
47 'Report of the school dental surgeon', in Twenty-third annual report of the school medical officer for the year ending 31st December 1930, Heston and Isleworth, 1931, p. 54. In seven cases free treatment was allowed, sometimes with rail fares paid.
} 


\section{S. Gelbier}

\section{The local clinic contribution}

Heston's dentist explained the intended treatment plan to the patient and parent, using the models and radiographs as visual aids. He then obtained the parent's signature to certify that the purpose and method of the proposed treatment was understood. Initially, it was assumed that about fifty cases each year would pay the fee of 37s. and accept orthodontic treatment. ${ }^{48}$ However, by May 1930, the clinic was rushed with applicants anxious to avail themselves of the facilities offered: thus more sessions than expected had to be devoted to the work. By the end of 1930, 143 children were seen in thirty-one two-and-a-half-hour sessions (see Table 5).

TABLE 5: DEFECTS FOUND IN THE FIRST 143 CASES IN 1930

\begin{tabular}{lr} 
Narrow arches & 16 \\
Labioversions & 20 \\
Linguoversions & 20 \\
General crowding & 32 \\
Interlocked bites & 2 \\
Suckers: lip & 3 \\
& \multicolumn{1}{c}{$\quad$ finger } \\
$\quad$ thumb & 2 \\
tongue & 1 \\
Open bite & 2 \\
Close bite & 12 \\
Perversions & 4 \\
Torsoversions & 14 \\
Supraversions & 2 \\
Inferior retrusions & 21 \\
Superior protrusions & 1 \\
Impacted teeth & 2
\end{tabular}

By January 1931, it was found that a maximum of 160 cases could be treated on the basis of one session per week. ${ }^{49}$ The dentist was assisted by a dental nurse and a mechanic; the latter taking verbal instructions and assisting with appliance adjustments.

Cohen emphasized the ease of carrying out the consultant's instructions owing to the lucid way in which the reports were written. Although the consultant stated what tooth movements were necessary, he left appliance design to the clinic dentist. Only removable appliances were used in 1930, fixed ones being excluded partly on the grounds of expense and partly because they required "more expert manipulation than the parents can be trusted to undertake". ${ }^{50}$ Appliances consisted of expansion screws, retraction wires, springs, screws or hickory pegs to move individual teeth, inclined planes, splint planes, labial wires, retention plates, lip exercisers, oral screens, and bite-raising appliances. In addition, breathing exercises were taught.

THE 1931 SCHEME

It had been hoped that a single visit to the hospital for a consultant's opinion and advice on treatment would suffice. However, an appreciable number of cases needed

${ }^{48}$ Ibid., p. 55.

49 Ibid.

so Ibid., p. 56. 


\section{Britain's first community orthodontic scheme}

a review at intervals of three, six, or twelve months. ${ }^{51}$ Sometimes, models only, rather than the patient, were sent, the Heston dentist deciding whether a case had progressed sufficiently to be reviewed at hospital.

In 1931, there was a further advance. The school dentist collected together these review cases at suitable intervals and Evans came out from the Royal to act as visiting orthodontist, seeing the cases at Heston's school clinic. He was paid three guineas per visit. During 1931, four Monday morning sessions were devoted entirely to orthodontics. An increasing proportion of children came from families unable to pay the full cost. ${ }^{52}$ The net cost of the scheme to Heston was approximately $£ 150$.

Cohen hoped to make permanent arrangements along those lines. ${ }^{53} \mathrm{Nash}$ also was convinced that full decentralization from the hospital was necessary. He emphasized to the education committee that orthodontic specialists must visit clinics in the same way as did orthopaedic specialists, and he stated the need for them to deal with their own radiograms, as that was the only stumbling-block to accomplishment of the scheme.

According to Nash, the provision of orthodontic care "raised the whole tone" of dental treatment. The public realized that behind this treatment-which hitherto in the popular mind had been associated merely with filling holes or pulling out teeth-was a scientific attempt to deal with the whole mouth, taking a long-term view instead of dealing merely with the existing situation. It thus put the whole of dentistry on to a higher plane. Nash also noted how mothers with bad deformities themselves-some of whom exhibited serious inferiority complexes as a result of their deformities-were now anxious to ensure that their children should have everything possible done to remedy defects similar to those which had overshadowed their own lives. ${ }^{54} \mathrm{He}$ felt strongly that orthodontic care must become an integral part of the day-to-day work of school dental clinics, and wrote: "It is only when one sees the mass of these cases and the woeful condition of some of these mouths from the point of view of deformity, that one realises how much has been neglected in the past." 55

\section{THE 1932 ORTHODONTIC SCHEME}

During 1932, 146 cases were taken on. Nash realized the need for more frequent visits to Heston by the orthodontist, with all patient visits to the RDH eliminated except in special cases. Thus is was that in August 1932, H.R. Evans, LDSRCSEng, was appointed as orthodontic specialist by the Heston and Isleworth education committee..$^{56}$ As he visited the local clinic monthly to see all new cases and review the old ones, it was less necessary to be quite so selective in choosing patients suitable for orthodontics, the norm elsewhere. This arrangement provided a major lesson for

\footnotetext{
51 'Report of the school dental surgeon', in Twenty-fourth annual report of the SMO for the year ending 31 st December 1931, Heston and Isleworth, 1932, p. 54.

52 Ibid., p. 57.

s3 Ibid., p. 55.

s4 Ibid.

ss Ibid.

so 'Report of the school dental surgeon', in Twenty-fifth annual report of the SMO for the year ending 31st December 1932, Heston and Isleworth, 1933, p. 27. However, on p. 5, Evans was listed as the orthodontic consultant.
} 


\section{S. Gelbier}

school services throughout the United Kingdom. No longer was it necessary to reside within easy reach of a dental hospital in order to obtain orthodontic treatment.

The mechanic was paid 7s. $6 d$. for each session. However, fewer dental models were needed, as the orthodontic specialist saw the actual patients at the clinic. Thus the amount paid during the year for the mechanic's fees plus cost of the materials and construction of appliances was only $£ 13115 \mathrm{~s} .11 \mathrm{~d} .^{57}$

During 1932, 451 orthodontic cases attended for initial advice and 342 for review, with 129 appliances being fitted.

\section{THE 1933 DEVELOPMENT}

In 1933, Nash reported: "Mr Evans has absorbed the Public Health spirit and from the amount he gets through, his work might also be classed among the sweated industries, as his morning sessions average some 65 cases." ${ }^{58}$ Such a throughput of patients might seem appalling. However, as Nash said, when one realizes "how rapidly those cases can be visualised and treatment dictated to the stenographer at the chairside", it will be understood that the problem was not as formidable as it appeared; but it was still too much.

During 1933, 337 cases attended for advice and 424 were reviewed; 117 appliances were fitted and 317 adjusted. Evans wrote: "It must be a matter of considerable pride... that the Orthodontic Section of the Heston and Isleworth Public Health Department represents the only such scheme now in operation which can claim the official recognition of the Board of Education."

The British Dental Journal joined in the praise, suggesting that the Heston and Isleworth scheme might well become a model for other boroughs. ${ }^{60}$ Evans emphasized the great debt of appreciation due to the RDH, especially to those staff who gave their opinions on the original cases submitted. Without them, it would have been impossible to establish a satisfactory orthodontic scheme. In particular, Evans emphasized the clinic's debt to the RDH's registrar, E. Faulknor Ackery. He said: "Only by reason of his personal interest and activities was it possible to interpolate the additional work emanating from the Clinic into the normal Hospital routine without causing grave inconvenience and delay to an institution already working at high pressure." 61

Evans indicated that he had always wanted to examine the subject of orthodontics in school clinics from the "dual angles of public authorities and the recipients of treatment". However, when first asked to co-operate in the formation of a complete orthodontic scheme, he was inclined to refuse. It seemed "totally impracticable to devote so much time to orthodontics without interfering seriously with the routine dental work of the clinic." "62 From the start, Evans was determined "to leave no stone unturned" in order to foster a satisfactory plan. He realized that in order to attain

s7 Ibid., p. 28.

${ }^{58}$ Annual report of the SMO for 1933, Heston and Isleworth, 1934, p. 16.

59 'Annual report of orthodontic consultant', in Report of the SMO for 1933, op. cit., note 58 above, p. 20.

${ }^{60}$ Notes, 'Orthodontics in school dentristry', Br. dent. J., 1934, 57: 598.

${ }^{61}$ Ibid.

es Ibid. 


\section{Britain's first community orthodontic scheme}

success in treating malocclusions, any scheme would have to be truly comprehensive, and not merely selective as was usually the case. Although he aimed to achieve adequate treatment for all patients with a single session each week, he feared it would prove harder to attain in practice than in theory. Nevertheless, by 1933, Evans was astonished but happy to report that his fears were unfounded.

By then, Evans claimed to deal with every patient demanding orthodontic treatment. He said the large measure of success attained in every case served to confound another argument sometimes put forward against the practice of orthodontics at school clinics. Here he was referring to an alleged inability of clinic staff to carry out a consultant's instructions successfully. He said that although treatment of orthodontic cases was a speciality, "I am glad to be able to place on record the fact that my instructions have invariably been followed to the letter, hereby contributing in no small measure to the steady continuance of success."

Obviously, in any organized service, co-operation is needed from the senior dentist. Evans duly acknowledged to the education committee the invaluable help given to him by Cohen. He also reminded them that cessation of the visits to London had relieved parents of a financial burden, and avoided much loss of time for both children and parents. By 1935, it was possible to reduce the fee to $15 \mathrm{~s}$. per consultation, plus 10 s. if an appliance was needed. ${ }^{64}$

\section{THE NEED FOR RADIOLOGICAL FACILITIES}

Initially, radiographs were taken at the West London Hospital. But in order to make the scheme self-contained, Evans emphasized the need to install a suitable $\mathrm{x}$-ray apparatus in the clinic. Realizing the expense involved, Cohen and Evans told the education committee that such equipment could also be used for other dental activities. Evans emphasized the need to ensure that the dental staff were sufficiently trained to operate the machine and interpret correctly the radiographs produced. To develop this expertise, Cohen suggested that Heston's dental surgeons should attend a short course of lectures on orthodontics and practical x-ray work. By 1936, the West London Hospital indicated that it would not be able to continue the work indefinitely. In 1937, Evans' wish was satisfied. In his annual report, Cohen wrote: "The long, long trail of waiting for the power 'to know' rather than 'to guess' a diagnosis ended in 1937, and we who had waited so patiently, perhaps impatiently, found our dreams come true; even then the opposition to be overcome, lent zest and energy to conquer those wishful to deprive us of our mess of pottage."

In July, a Victor dental x-ray machine was installed in the Busch House clinic, opened in 1934 after a fire at the Clipstone House clinic in Isleworth. Cohen said: "The dental staff are still waiting for a withdrawal of aspersions upon their abilities to produce good skiagrams; it is long overdue." He reminded everyone that Heston and Isleworth were again ahead of the rest of the country. Using his considerable literary skills to the maximum, Cohen emphasized that the figures appended to his report

${ }^{63}$ Ibid.

4. 'Annual report of orthodontic consultant', in Twenty-eighth annual report of the SMO for 1935, Heston and Isleworth, 1938, p. 19.

${ }_{65}$ 'The annual report of 1937 of the supervisory dental officer', in Thirtieth annual report of the SMO, Heston and Isleworth, 1938, p. 28. 


\section{S. Gelbier}

"do not speak, they shout to other clinics to rouse themselves, and follow the pioneer lead of only three clinics in England including ours, that have these machines." They would save time and expense, but above all: "They will be able to do with greater certainty and give more knowledgeable diagnosis, which is the unalienable right of their patients to receive."

Ever aware of the need to satisfy the borough councillors (the urban district having become a borough in 1932), Cohen pointed out how much money would now be saved by taking radiographs locally: the cost of skiagrams produced at hospital was $5 s .7 d$., whilst that for pictures produced on Heston's own apparatus was $1 s .1 d$.; and, of course, travelling costs were also reduced.

\section{THE NATIONAL VIEWPOINT}

Important though Heston was to him, Evans had a wider vision. He wanted the lessons gained there to be applied nationally. Evans said there had become available a wealth of practicable experience: "Of more worth in aiding the evolution of a possible National Orthodontic Scheme than any amount of erudite theories, however academically correct the latter might be." ${ }^{\text {B8 }} \mathrm{He}$ emphasized that the work of the orthodontic section had served as invaluable propaganda amongst the parents of local children. The progressive enlargement of a sympathetic understanding by parents would do much to ease the way for earlier and more complete treatment of developing malocclusions. Although dental health education could mean an enhanced treatment load, Evans had every confidence that the dental staff would be ready and willing to handle as many cases as came their way. He wrote: "The idea, so firmly fixed in the minds of many parents, that cases of malocclusion or irregularities should be left alone for Nature to cure, is one of the hardest hindrances which have to be overcome." ${ }^{87}$ However, since the clinic had effected so many successes, the barriers of indifference and prejudice were slowly breaking down. On more than one occassion, parents had eventually given their ungrudging approval and appreciation of services rendered. As Evans said to the committee: "Time will show whether this greatly to be desired orientation of outlook on the part of the parents may be the prelude to a larger and more national conversion to the acceptance of the Orthodontic Scheme." 68

In promoting his belief that it was feasible to inaugurate orthodontic clinics throughout the land, he went on: "The results in this pioneer Borough are most encouraging .... I look forward with confidence to the eventual extension of the Scheme on National lines."

Evans aimed to prevent orthodontic anomalies rather than only to effect cures. ${ }^{69}$ He frequently treated cases by judicious extraction of teeth, trusting in the power of nature to complete the process. Evans felt that early treatment would prevent more serious problems from arising. He concluded his 1933 report thus: "Experience ... warrants the assumption that the practice of orthodontics in school clinics throughout the country is wholely desirable and eminently practicable."70

es 'Annual report of orthodontic consultant' in Report of SMO for 1933, op. cit., note 58 above, p. 21.

Ibid.

${ }^{\text {es }}$ Ibid.

${ }^{80}$ Ibid. p. 22.

${ }^{70}$ Ibid. 


\section{BOROUGH OF HESTON AND ISLEWORTH EDUCATION COMMITTEE}

\section{REPORT OF THE ORTHODONTIC SPECIALIST TO THE SCHOOL} MEDICAL OFFICER

This Report is historic in that it is the first Report by an Orthodontic Specialist appointed to a Municipal Dental Clinic in Great Britain.

E. H. T. NASH, M.r.c.S. L.R.c.P., D.P.H. Medical Officer of Heallh and School Medical Officer.

Figure 1. Cover of the report of the orthodontic specialist. (Reprinted from the 1933 annual report of the school medical officer.)

In order to publicize his feelings Evans promoted the reprinting of his section of the 1933 SMO's report (Figure 1). He said that Heston had already incurred the gratitude of the dental profession both for the original conception of its pioneer scheme and for putting the preliminary plans into operation. He emphasized to the 


\section{S. Gelbier}

education committee that if the scheme received recognition and approval from the Board of Education and was eventually adopted throughout the country, the nation as a whole would be indebted to them. He was looking forward to the time when the orthodontic section of the Heston and Isleworth dental clinic was acknowledged by similar clinics throughout the land: "Not only as the leading spirit in such work but also as a continued model of success for all centres". ${ }^{71}$

Certainly, by 1933, Evans' work was attracting attention nationally. The Board of Education pointed out that Evans had been appointed by Heston and Isleworth as its orthodontic consultant. ${ }^{72}$ It indicated that the striking photographs in his Heston report (Plates 1 and 2) showed beyond doubt the value to the patients. But the benefits obtained were not confined to these children. They served "to raise the status of the clinic generally in the eyes of the public".

However, not everyone thought that the introduction of orthodontic specialists was a good idea. Grantley Smith, president of the Dental Group of the Society of Medical Officers of Health, challenged Nash at a meeting of the Group in 1933. He reminded him that the curriculum set by the Royal College of Surgeons of England for its Licence in Dental Surgery examination included a "comprehensive training in orthodontics". ${ }^{33}$

\section{RETIREMENT OF NASH}

In 1936, Nash was awarded the Membership of the Royal College of Physicians. 1937 was the last complete year in which he served Heston and Isleworth. In his Annual report for that year, which he signed in June 1938, Nash wrote proudly that the establishment of a complete orthodontic scheme with some 2,000 cases treated was a landmark in the progress of municipal dentistry and: "So far as I can ascertain our orthodontic clinic is the first municipal orthodontic clinic in the English speaking world, neither can I find the history of any in those who do not speak our tongue."74 Nash clearly felt both a responsibility and pride in the development of that clinic. He wrote: "The succes of this work has been one of the principal joys of one's work. The gratitude of the mothers, speaking generally, is wonderful, and the difficulties of bringing the scheme to fruition fade into insignificance beside the results achieved."

In that same report, he paid tribute to Cohen, writing that he had, with "dental skill and thoroughness", made an invaluable contribution to the success of the scheme. However, even in the last few months there was still an atmosphere between them. Early in 1938, A.T. Wynne, MB, BDS, FDS, a dentally qualified medical officer of the Board of Education, reported: "Dr Nash did not impress me favourably. It is evident that there is a great deal of ill feeling between him and Mr Cohen ... a considerable part of the time of our interview was spent by Dr Nash in reviling $\mathrm{Mr}$ Cohen's character and conduct."75 He went on: "I imagine that Dr Nash, who is somewhat conceited because of his high reputation in the dental world gained from

\footnotetext{
71 Ibid.

${ }^{72}$ Annual report of the CMO of the Board of Education, 1933, p. 122.

${ }^{73}$ See J.F. Pilbeam and K.C.B. Webster, 'Orthodontics in the school dental service', Public Health, 1933, 46: 201.

${ }^{74}$ Report on the health of the borough of Heston and Isleworth for the year 1937, 1938, p. 10.

${ }^{75}$ Report by A. T. Wynne to Board of Education, signed on 6 October 1938, in PRO/ED 137/98.
} 


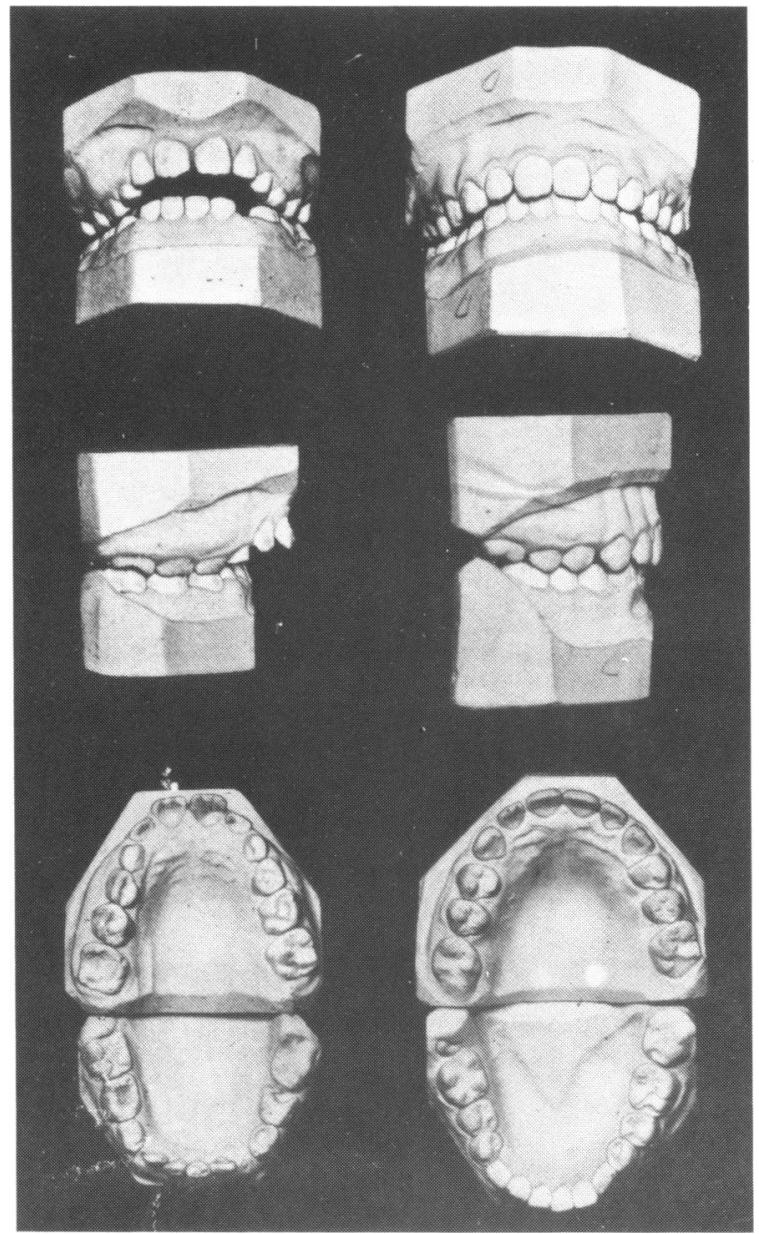

Plate 1. Treatment of a nine-year-old girl illustrated in the 1933 annual report. Models on the left show case before treatment. 


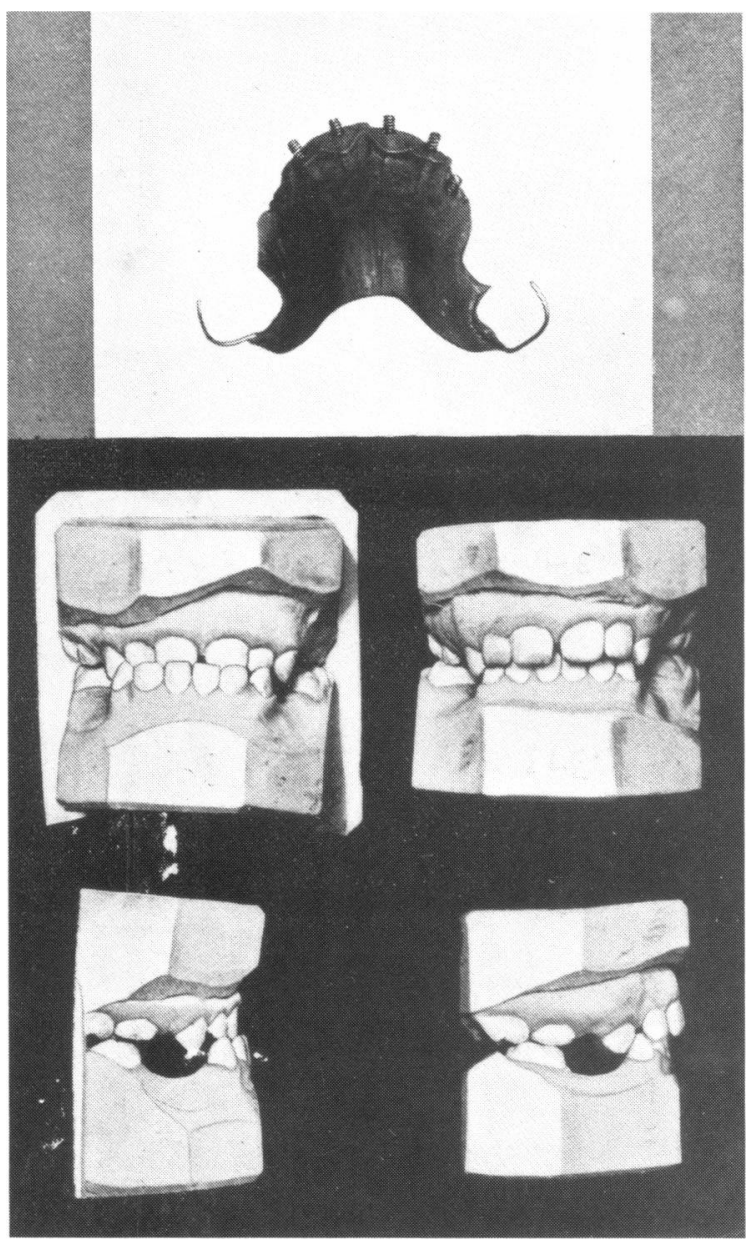

Plate 2. Models illustrating treatment of a ten-year-old boy, using vulcanite plate and screw appliance to push upper incisors over and in front of the lower incisors. 
the orthodontic scheme, has tended to interfere unduly with the running of the dental service, to Mr Cohen's justifiable annoyance."

At least Wynne recognized Nash's important contribution. He was not impressed by Cohen either, and stated: "Although he was on the best behaviour when I saw him, I judge that on occasion he can be extraordinarily objectionable. During our interviews he was decidedly unhelpful and evasive and appeared to use his deafness as a defence against criticisms." Wynne went on that, in his turn, Cohen abused Nash, and between the two of them it was very difficult to ascertain the true state of certain dental matters. Eventually Wynne hàd to turn for help to Miss W. Smith, the senior dental clerk. Wynne said she was able to handle Cohen better than most, and indeed, without her, the results of his conversations with Cohen would have been "very meagre". With such problems between the people concerned it is surprising that any dental schemes could develop, let alone one of a specialist orthodontic nature. But it did!

Whatever Cohen felt, Evans certainly admired Nash. When the latter was retiring, Evans wrote to say how greatly he had appreciated the opportunity of being associated with Nash in connexion with the pioneer work, always finding him to be extremely helpful and enthusiastic. ${ }^{76}$ Indeed, he went on: "Should the time arrive (as I am certain it must) when the orthodontic scheme becomes in fact a National institution it will undoubtedly be almost entirely due to the foresight and untiring efforts which Dr Nash has for so long exercised."

Even Cohen was generous enough to say some kind things about Nash on the latter's retirement. Although a few of his comments were perhaps a trifle double-edged, he brought out some of his best poetry and prose for the occasion. In Nash's final Annual report Cohen wrote 'A Personal Note' for Nash:

Fare thee well,

Sooner or later, must come the hour

when closest friends must say

FAREWELL. ${ }^{\text {? }}$

He finished his note by suggesting that neither of them waste time in vainly regretting the past, nor in complaining against the changes that caused them discomfort, ending with a quote from Byron:

Long shall we seek his likeness - long in vain

And then turn to all of him, which may remain

Sighing that Nature formed one such man,

And broke the die - after moulding Nash.

And so in 1938, Nash took leave of Heston and Isleworth, retiring to Chelmsford in Essex. In that same year, the Society of Medical Officers of Health made him their President. Nash died late in 1941.

\section{CONCLUSION}

How little did the Urban District Council of Heston and Isleworth know in 1924 exactly what it was starting. Orthodontics is now widely practised throughout the

76 'Annual report of the orthodontic consultant' in Annual report of the SMO for 1937, 1938, p. 34.

77 'Annual report of 1937 of the supervisory dental officer', in Annual report of the SMO for 1937, op. cit., note 65 above, p. 31 . 


\section{S. Gelbier}

United Kingdom in community health centres (successors to school clinics). In 1965, the first year of operation of the new London borough of Hounslow's Health Department (which incorporated the district of Heston and Isleworth), 509 children attended for orthodontic treatment and 299 appliances were fitted. Only four had to be referred for hospital advice. ${ }^{78}$ By 1980, in England alone 35,981 new patients attended for actual orthodontic treatment, apart from those who went for advice only. In that year 55,276 removable and 6,508 fixed appliances were fitted; 23,908 cases were completed. These figures are a fitting memorial to Nash, Evans, Cohen, and Heston and Isleworth's education committees: all played an essential part in the development of this first community orthodontic scheme.

\section{ACKNOWLEDGEMENTS}

My sincere thanks are due to Mr D.H. Norman, formerly chief dental officer of Hounslow. It was he who brought to my attention the records of the early orthodontic facilities, which had been retrieved from the fire at Clipstone House. Thanks are also due to the Photographic Department of King's College School of Medicine and Dentistry for providing the illustrations.

${ }^{78}$ The health services of Hounslow: annual report of the medical officer of health and school medical officer 1965, 1966. 